
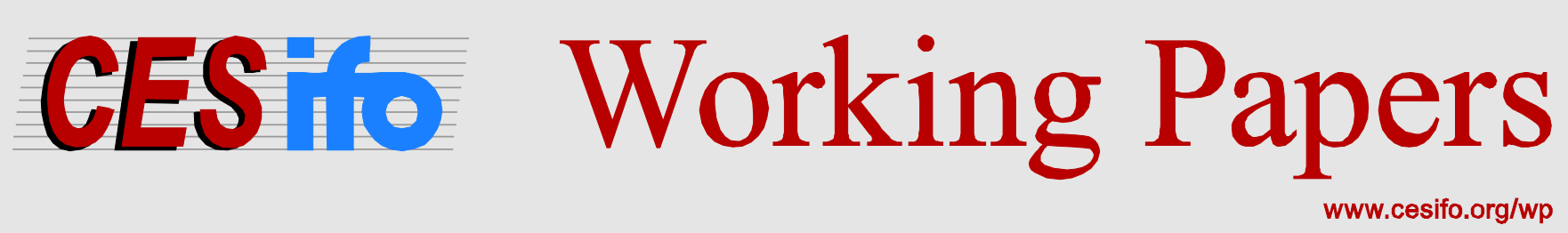

\title{
Neighborhood Racial Characteristics, Credit History, and Bankcard Credit in Indian Country
}

\author{
Valentina Dimitrova-Grajzl \\ Peter Grajzl \\ A. Joseph Guse \\ Richard M. Todd \\ Michael Williams
}

CESIFO WORKING PAPER NO. 5594

CATEGORY 11: INDUSTRIAL ORGANISATION

Original VERSION: NOVEMBER 2015

THIS VERSION: NOVEMBER 2017

An electronic version of the paper may be downloaded

- from the SSRN website:

- from the RePEc website:

wWw.SSRN.com

www.RePEc.org

- from the CESifo website:

www.CESifo-group.org/wp 


\title{
Neighborhood Racial Characteristics, Credit History, and Bankcard Credit in Indian Country
}

\begin{abstract}
We examine whether concerns about lenders' discrimination based on community racial characteristics can be empirically substantiated in the context of neighborhoods on and near American Indian reservations. Drawing on a large-scale dataset consisting of individual-level credit bureau records and utilizing approaches that aim to isolate supply from demand considerations, we find that residing in a predominantly American Indian neighborhood is ceteris paribus associated with lower awarded bankcard credit limits than residing in a neighborhood where the share of American Indian residents is low. We further find that consumer's credit history is a robust and quantitatively more important predictor of awarded bankcard credit limits than racial composition of the consumer's neighborhood, and that the awarded bankcard credit limits do not depend on the consumer's location vis-à-vis a reservation.
\end{abstract}

JEL-Codes: G210, J150, P430, R110.

Keywords: bankcard credit, American Indian reservations, discrimination, neighborhood racial characteristics, credit history.

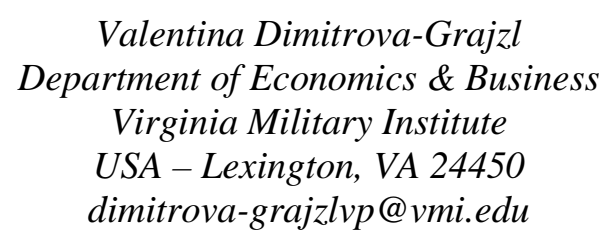

A. Joseph Guse

Department of Economics

Washington and Lee University

USA - Lexington, VA 24450

gusej@wlu.edu

\author{
Richard M. Todd \\ Community Development Department \\ Federal Reserve Bank of Minneapolis \\ USA - Minneapolis, MN 55401 \\ dick.todd@mpls.frb.org
}

Peter Grajzl

Department of Economics

Washington and Lee University

USA - Lexington, VA 24450

grajzlp@wlu.edu

\author{
Michael Williams \\ Community Development Department \\ Federal Reserve Bank of Minneapolis \\ USA - Minneapolis, MN 55401 \\ Michael.Williams@mpls.frb.org
}

November 12, 2017

For helpful comments we thank Randall Akee, Kenneth Brevoort, Donna Feir, Dan Gorin, Song Han, Henry Korytkowski, Geng Li, Michael Mathes, Bryan Noeth, Jaromir Nosal, Joe Ritter, Jonathan Taylor, Judy Temple, Ping Wang, Jim West, an anonymous credit card industry expert, and participants at the Federal Reserve System's Community Development Internal Research Symposium as well as at annual meetings of the Regional Science Association International, the Midwest Economic Association, and the Association for Public Policy Analysis and Management. Each author notes that the views expressed here are theirs and not necessarily those of the Federal Reserve Bank of Minneapolis or the Federal Reserve System. 


\section{Introduction}

Credit cards are a widely available form of consumer credit in the United States. The majority of American households have at least one credit card, most often a bank-issued general purpose card, or bankcard. Over 70 percent of households regularly make payments with credit cards (Schuh and Stavins 2014); nearly 40 percent use credit cards to borrow in a given month (Bricker et al. 2014); and about 65 percent apply for a credit card in a given year (Larrimore et al. 2015). Bankcards are often a vehicle through which young consumers establish a credit history that opens the door to homeownership (Debbaut et al. 2014). Bankcards and the credit they provide are thus a consumer mainstay, facilitating transactions, consumption smoothing, household financial risk management, and, for many small-scale entrepreneurs, business finance.

Given the value of bankcards to consumers, it is not surprising that policymakers have tried to ensure fair access to this type of credit. ${ }^{1}$ Yet concerns persist about unequal access to and usage of bankcards in minority communities (see, e.g., Skanderson and Ritter 2014). ${ }^{2}$ Indeed, the general topic of discrimination in credit markets has been an important area of research in economics (see, e.g., Tootell 1996, Ladd 1998, Blanchflower et al. 2003, Dymski 2006). Systematic research on discrimination in credit card markets, however, is scant because publicly available data on access to and usage of credit cards are limited to the Survey of Consumer Finance (SCF) and a few other small, nationally (but not regionally) representative surveys.

Using data from the 2010 SCF, Firestone (2014: 1206), for example, shows that "after controlling for many factors...Blacks and Hispanics are both less than half as likely as others to

\footnotetext{
${ }^{1}$ For example, the Equal Credit Opportunity Act prohibits discrimination against protected classes in extending credit. See also Skanderson and Ritter (2014).

${ }^{2}$ In a recent major federal credit card discrimination settlement, the GE Capital Retail Bank was accused of deceptive marketing and discrimination against Hispanics. The Consumer Financial Protection Bureau and Department of Justice ordered GE Capital to pay \$225 million in relief. See http://www.justice.gov/opa/pr/justicedepartment-and-consumer-financial-protection-bureau-reach-169-million-settlement.
} 
have at least one credit card", a finding consistent with an analysis of earlier SCF data by Bertaut and Haliassos (2006). Using similar data from mailings, Han et al. (2013) find that white consumers are more likely to receive a credit card offer and to be offered favorable terms than minority consumers with comparable risk profiles. Cohen-Cole (2011) and Brevoort (2011) use proprietary credit history data to examine discrimination by neighborhood racial characteristics (so-called redlining). Cohen-Cole (2011) reports evidence that credit card issuers systematically gave residents of African-American neighborhoods lower credit limits than they gave to individuals with similar financial credentials living in similar, but non-African-American, neighborhoods. Brevoort (2011), however, raises a series of methodological concerns about Cohen-Cole's (2011) approach and demonstrates the lack of robustness of Cohen-Cole's findings.

Similar concerns have been raised about access to and usage of consumer credit, including bankcards, for American Indians and American Indian communities-"America's domestic emerging market" (Clarkson 2009: 287)—for which research has been particularly scarce even though undersupply of credit had been identified as a key obstacle to economic progress of American Indian reservations (see, e.g., Community Development Financial Institutions Fund 2001, Parker 2012, Brown et al. 2015, Native Nations Institute 2016). ${ }^{3}$ Dimitrova-Grajzl et al. (2015) use the Federal Reserve Bank of New York/Equifax Consumer Credit Panel (CCP) data aggregated at the Census block group-level to show that usage of some types of consumer credit is lower within reservations (based on simple correlations) and areas with a high percentage of American Indian residents (after controlling for an array of factors).

\footnotetext{
${ }^{3}$ For references to empirical studies on various aspects of economic development in Indian Country, see Section 1 in Dimitrova-Grajzl et al. (2015).
} 
Among the types of credit with lower usage identified by Dimitrova-Grajzl et al. (2015) is unsecured consumer credit, including bankcard credit. ${ }^{4}$

In this paper, we likewise draw on the CCP data, but in contrast to Dimitrova-Grajzl et al. (2015) examine the determinants of individual-level bankcard credit outcomes in neighborhoods on and near American Indian reservations (referred to here as Indian Country). The CCP data do not allow us to observe individual's race. Therefore, much like Tootell (1996), Campbell et al. (2008), Cohen-Cole (2011), and Brevoort (2011), we focus on the impact of neighborhood (as opposed to individual) racial characteristics on individuals' credit outcomes. Unlike the existing literature, however, we examine whether concerns that bankcard issuers make lending decisions based on the racial composition of the borrower's neighborhood—an act that would constitute "a clear violation of the Equal Credit Opportunity Act" (Brevoort 2011: 714)—can be empirically substantiated in the context of Indian Country. To this end, we use reduced-form empirical models that strive to isolate supply from demand considerations and employ a wide range of individual and neighborhood level controls as well as fixed effects to explore if the awarded bankcard credit limits for individuals who reside in Indian Country neighborhoods with a high share of American Indian residents all else equal differ systematically from the awarded bankcard credit limits for individuals who reside in Indian Country neighborhoods with a lower share of American Indian residents.

Our main findings may be briefly summarized as follows. First, residing in an Indian Country neighborhood with a high share of American Indian residents is, after controlling for a wide range of factors, associated with statistically significantly lower bankcard credit limits than residing in an Indian Country neighborhood with a low share of American Indian residents. This

\footnotetext{
${ }^{4}$ Earlier assessments of redlining of non-mortgage consumer credit on reservations, using interviews and reports from local experts, include Pickering and Mushinski (1999) and Community Development Financial Institutions Fund (2001).
} 
result is robust across specifications and, at the very least, consistent with the possibility that bankcard issuers in Indian Country discriminate based on neighborhood racial composition. Due to our inability to exploit a true experimental research design, however, our results should not be interpreted as conclusive evidence of discrimination.

Second, an individual's credit history, as captured by an individual's Equifax Risk Score and recent history of bankruptcy, overall exhibits an economically large and robustly statistically significant effect on individuals' bankcard credit outcomes. This finding suggests that despite the many institutional and developmental specifics that differentiate Indian Country from the rest of the U.S. (see, e.g., Pommersheim 1989, Cornell and Kalt 1992, Jorgensen 2007), the generally applicable result about the crucial importance of an individual's credit history for future credit outcomes (see, e.g., Gross and Souleles 2002a, 2002b; Avery et al. 2010, Board of Governors 2007) fully extends to the thus far unexplored group of consumers residing in neighborhoods on and near American Indian reservations. In particular, a 2007 report by the Board of Governors of the Federal Reserve already established "a strong relationship between credit scores and the incidence of new credit" across a wide range of population groups in the U.S. (Board of Governors 2007: O-16). That study, however, included a very small sample of (fewer than 1,400) American Indian consumers (Board of Governors 2007, Table 9). We, in contrast, draw our conclusions based on analysis of a notably larger sample of consumers residing exclusively in Indian Country and quantify the effect of the Equifax Risk Score on awarded bankcard credit limits as the outcome of interest.

Third, an individual's location vis-à-vis a reservation or off-reservation tribal land does not matter for any of the bankcard credit outcomes we examine. This result resonates with the findings on unsecured credit of Dimitrova-Grajzl et al. (2015), who use geographically 
aggregated data, for various categories of consumer credit. It further suggests that, if lenders in Indian Country do make unsecured lending decisions based on certain characteristics of the borrower's neighborhood, then the consumer's location relative to a reservation or off-reservation trust land does not seem to be among them.

The rest of the paper is organized as follows. Section 2 introduces the data. Section 3 develops the empirical strategy. Section 4 presents the results. Section 5 concludes.

\section{Data ${ }^{5}$}

\subsection{The Federal Reserve Bank of New York/Equifax Consumer Credit Panel}

To examine bankcard credit outcomes in Indian Country, we draw on the Federal Reserve Bank of New York/Equifax Consumer Credit Panel (CCP). The CCP is an anonymous, nationally representative five-percent sample of the credit history files of U.S. residents. We draw on the CCP primary files which cover about 12 million randomly chosen consumers. ${ }^{6}$ Lee and van der Klaauw (2010) assess the representativeness of the CCP with respect to the full population of adults by comparing the data in the 2008 CCP primary files with corresponding estimates from the 2008 American Community Survey for select geographies and from the Survey of Consumer Finance. Their findings suggest that the CCP is generally representative of the U.S. population of adults aged 20 or more and their credit usage. ${ }^{7}$ In order to focus on the working-age population, we examine credit files of consumers who are between 18 and 70 years old.

\footnotetext{
${ }^{5}$ This section draws heavily on the analogous section in Dimitrova-Grajzl et al. (2015).

${ }^{6}$ The primary sample is selected on the basis of the last two digits of individuals' social security numbers. Everyone whose number has one of five two-digit combination is included. The full CCP further includes additional householder files for non-randomly selected individuals who have the same address as a randomly selected individual.

${ }^{7}$ However, there are caveats with respect to the representativeness of the CCP for reservation populations. First, the percentage of adults with no credit file or thin credit file may be higher on reservations, given widespread reports that credit is hard to access there. Second, Lee and van der Klaauw (2010) do not examine small rural geographies and thus provide no direct assessment of the accuracy of address information (and thus the accuracy of the CCP's Census block data) for these geographies. Third, accurate address information also could be problematic for
} 
The credit information in the CCP is extensive. For each consumer in the sample, the CCP reports their total number of bankcards, the total credit limit and balance owed on those cards, and the total amount of bankcard balances by repayment status. Credit files with sufficient credit performance history include an Equifax Risk Score, which ranges from 280 to 850, with a lower score indicating a higher level of estimated credit risk. Consumers whose credit histories are 'thin' do not have an Equifax Risk Score. The CCP further provides a code for the Census block of the address that the bureau assigns to each file; this information enables us to combine CCP data with Census data (see below). While the CCP also includes the consumer's year of birth, it provides no other demographic information. In particular, the CCP does not include information about individual's race and income. The CCP also does not report any information about the contractual terms of consumer's debt or the lenders.

\subsection{Our Sample}

Our sample is designed to incorporate geographic areas with high concentration of American Indian population. We begin by identifying all federally recognized American Indian Reservations whose population on the reservation or any associated off-reservation trust land had at least 200 adults according to the 2000 Census. ${ }^{8}$ We then include in our sample all Census blocks on these reservations, the off-reservation trust land, as well as any Census block within ten miles $(16 \mathrm{~km})$ of the reservations and trust lands. Since Census block boundaries never cross

reservations that include a large share of seasonally or intermittently mobile households moving frequently between the reservation and regional urban areas.

${ }^{8}$ An Indian reservation for our purposes is any area in the United States with a tribal area Census code between 1 and 4999 and at least some land recognized by the Census as reservation land. This excludes tribal statistical areas (e.g., Oklahoma Tribal Statistical Areas and State Designated Tribal Statistical Areas) which are assigned tribal area Census codes above 5000. It also leaves out 6 tribal areas whose codes have values below 5000 but whose territory consists entirely of trust land (e.g., "Minnesota Chippewa Trust Land": Census code 2285). Finally, we exclude consumers located in Alaska and Hawaii. For further information on the geographies we use, see Dimitrova-Grajzl et al. (2015). 
reservation boundaries, we can unambiguously assign blocks to reservations, trust lands or to nearby non-tribal lands. ${ }^{9}$

The credit files that we analyze from CCP data are for individuals residing on in the geographic sample area during the years 2002-2007. We choose the first quarter of year 2002 as the beginning period for our sample because the CCP is geographically less precise prior to that (Wardrip and Hunt 2013). We select the last quarter of year 2007 as the end period of our sample because starting from 2008 the financial turmoil and subsequent policy responses significantly changed the credit environment (see, e.g., Jambulapati and Stavins 2014). Furthermore, the chosen end period reflects the fact that we combine CCP individual-level data with year 2000 Census data on the neighborhoods in which individuals reside.

We define the average penetration rate as the ratio of all credit files in a given quarter to Census population in year 2000, where both the number of credit files and population are measured at the level of a reservation or the area associated with a particular reservation. The average penetration rate for our full sample (reservations and off-reservation trust land together) is about 0.047 based on both the first quarter of year 2002 and the last quarter of year 2007 . The $\mathrm{CCP}$ is a five-percent sample and not all adults in Indian Country are likely to possess a credit record. Thus, the average penetration rate is broadly consistent with the expectations as well as steady over time. The average penetration rate for the on-reservation subsample is somewhat lower than the average penetration rate for the off-reservation subsample (e.g., 0.043 versus 0.053, respectively, based on the last quarter of year 2007) and exhibits a moderate increase over time (from 0.038 in the first quarter of 2002 to 0.043 in the last quarter of 2007).

\footnotetext{
${ }^{9}$ Census blocks have an average population of about 28 people, but this ranges from zero in millions of rural blocks to hundreds in some urban blocks. While in urban areas blocks are often city blocks bounded by city streets, in rural areas blocks may be much larger in area.
} 
The share of files without an Equifax Risk Score in the first quarter of year 2002 is 6.2 percent for the full sample, 8.3 percent for the on-reservation subsample, and 6.1 percent for the off-reservation subsample. There are three main reasons why the share of files without an Equifax Risk Score is higher on reservations that off reservations (see Dimitrova-Grajzl et al. 2015). First, reservation populations are on average younger populations and thus have less experience with credit markets. Second, limited access to banks on reservations slows the accumulation of credit experiences needed to produce an Equifax Risk Score. Finally, the status of trust land, which is predominantly located on reservations, makes it difficult for individuals to obtain mortgages and thereby build credit history. The share of files without an Equifax Risk Score in the last quarter of year 2007 is somewhat higher than in the first quarter of 2002 for all three samples $(6.8$ percent for the full sample, 9.7 percent for the on-reservation subsample, and 6.7 percent for the off-reservation subsample). This likely reflects the fact that over time new consumers with limited credit histories entered the credit market.

In empirical analysis in the rest of the paper, we focus only on those individuals in the sample who had no bankcards at least at one point between years 2002 and 2007 . We thus examine the credit files of more than 289,000 consumers who reside in one of more than 115,000 census blocks that lie within ten miles $(16 \mathrm{~km})$ of reservations or off-reservation trust lands. Table 1 provides variable descriptions for our outcome variables (panel A) and key explanatory variables (panel B). Table 2 present the descriptive statistics for our key variables. The relatively low mean share of American Indian residents (between 4.1 and 4.9 percent) associated with an observation (consumer in a given quarter) drawn randomly from one of our samples is consistent with the analogous block group-level aggregated statistic reported by Dimitrova-Grajzl et al. (2015: Table 2) and reflects the fact that many of the near-reservation blocks included in our 
sample are located in densely populated urban areas with a low share of American Indian residents. We measure other demographic and economic characteristics of neighborhoods at the Census block group level. ${ }^{10}$ We include a wide range of block group-level Census controls, listed and defined in Table A1, in our regressions to mitigate potential omitted variable bias (see Sections 3 and 4). However, because the effects of these controls are not of direct interest in themselves, we neither present nor discuss our estimates of the respective coefficients. Finally, depending on the outcome variable we consider (see Section 3.1 below), the share of consumers with a first mortgage (not shown in Table 2) in our estimating sample varies between 11 percent and 21 percent.

\section{Empirical Strategy}

\subsection{Outcome Variables}

To study the effect of neighborhood racial characteristics and an individual's credit history on supply of bankcard credit, we follow Cohen-Cole (2011) and Brevoort (2011) and examine total awarded bankcard credit limit as the outcome of interest. Conceptually, our focus on credit limits rather is predicated on the rationale that, amidst the ever-tightening governmental regulatory oversight aimed to ensure fair access to credit, exercising discretion in awarding credit limits constitutes a comparatively harder-to-detect, and thus for the lenders plausibly increasingly more attractive, means to discriminate based on neighborhood racial characteristics than does the more-often studied lenders' credit approval or denial decision. Accordingly, it is important to attempt to ascertain if any evidence of neighborhood racial characteristics-based disparities in awarding credit limits can be uncovered in the data. Furthermore, unlike credit balances, which

\footnotetext{
${ }^{10}$ Block groups generally aggregate dozens of blocks and typical have a population of 600 to 3,000 individuals. Their boundaries can and do cross reservation boundaries, so that some block groups may lie partly in and partly out of a given reservation.
} 
largely reflect demand for credit, credit limits have been viewed as primarily capturing credit supply (see, e.g., Gross and Souleles 2002a, Coibion et al. 2014). However, since an individual's total credit limit aggregated across all bankcards inter alia depends on the number of credit cards that an individual chooses to maintain, aggregate credit limits nevertheless reflect both supply and demand considerations (see, e.g., Brevoort 2011: 723).

To better isolate supply from demand considerations, we consider only individuals currently without a bankcard who obtain one or more bankcards in the next quarter. Our first outcome variable, First Credit Limit, is defined as an individual's total credit limit on the new bankcards in the next quarter. So-defined first awarded bankcard credit limit is by definition independent of recent bankcard usage that likely reflects demand considerations. However, the sample of consumers for whom First Credit Limit is defined includes both consumers who have previously never possessed a bankcard and consumers who currently do not possess a bankcard but had possessed one previously, at least two quarters before the new limit is awarded. To the extent that past bankcard usage affects demand for credit, First Credit Limit may nevertheless still reflect both credit supply and credit demand considerations. To even better isolate supplydriven from demand-driven factors of credit limits, we also consider only individuals who have previously never possessed a bankcard and who obtain one or more bankcards in the next quarter. Our second outcome variable, First Ever Credit Limit, is defined as an individual's total credit limit on the new bankcards for the subsample of individuals who never previously possessed a bankcard. ${ }^{11}$ Note that an individual may contribute multiple observations to our First

\footnotetext{
${ }^{11}$ Our approach assumes that individual-specific credit limits are part of equilibrium credit card contracts and that lenders adjust the limits they offer in response to borrower's credit history and other characteristics. Chatterjee et al. (2007) provide a theoretical framework for these assumptions in a framework designed to reflect U.S. legal institutions and the key features of U.S. consumer credit data.
} 
Credit Limit sample but can never contribute more than one observation to our First Ever Credit Limit sample. $^{12}$

\subsection{Focal Explanatory Variable}

Our key explanatory variable of interest, Share American Indian, captures the racial composition of the neighborhood in which an individual resides and is defined as the share (bounded between zero and one) of adult population in a Census block that identifies as American Indian. Figure 1 shows the distribution of this variable for three different groups of blocks. All three distributions are highly asymmetric and positively skewed (the mean exceeds the median and the mode). The overall percent of blocks with a high share of American Indians is greater for blocks located on the reservations or off-reservation trust land than for blocks located off the reservations or offreservation trust land.

\subsection{Individual Level Controls}

At the individual level, we control for an individual's Equifax Risk Score by including a full set of indicator variables for quintiles of the Equifax Risk Score distribution based on our full sample. This method of controlling for the relative magnitude of an individual's Equifax Risk Score allows for non-linear effects and is intended to minimize any bias arising from functional form misspecification (see, e.g., Han et al. 2013). For the same reason, we also control for individuals' age via inclusion of a full set of age cohort dummies. To control for any additional effect of an individual's credit history potentially not captured by individual's Equifax Risk Score, we control for the history of recent bankruptcy filings. Han et al. (2013) and Chatterjee et

\footnotetext{
${ }^{12}$ Consider an individual whom we observe for five consecutive quarters with a sequence of bankcard account observations $\{0,1,1,0,1\}$, where 0 denotes absence of a bankcard account and 1 its presence. Then this individual contributes two observations to our First Credit Limit sample: the first one consisting of individual level controls from the first quarter and credit limit from the second quarter and the second one consisting of individual level controls from the fourth quarter and credit limit from the fifth quarter. In contrast, assuming that the card obtained in the second quarter can be verified as truly first ever based on the observable age of the oldest bankcard, this individual contributes only one observation to our First Ever Credit Limit sample.
} 
al. (2007), for example, show that theoretically and in U.S. data, consumer's bankruptcy history indeed impacts credit card offers. We further allow for time since recent bankruptcy filing to exhibit a potentially non-linear effect. We thus include two indicator variables based on the information readily available in the CCP dataset: an indicator for whether bankruptcy filing took place in the last two years and an indicator for whether bankruptcy filing took place in the last ten years (including possibly within the last two years). Thus, in the regressions the effect of having filed for bankruptcy within the last two years is captured by the sum of the coefficients on the two bankruptcy indicator variables. The effect of having filed for bankruptcy between two and ten years ago is captured by the coefficient on the second indicator variable.

\subsection{Census Block Group Level Controls and Fixed Effects}

In order to mitigate the confounding effect of unobserved factors which may affect bankcard credit limits and, at the same time, correlate with our Census block-level measure of racial neighborhood composition, we include a wide range of socio-economic controls utilized by Cohen-Cole (2011) and Brevoort (2011). In particular, in the absence of information about individual level income, we follow Cohen-Cole (2011) and Brevoort (2011) and rely on Census 2000 block group level percentage of population with certain income. Other Census 2000 block group level controls inter alia include percentage of population with certain education, marital status, employment, and housing, as well as share of population that is black and Hispanic (see Table A1 for detailed list).

We also control for an individual's location relative to the on-reservation or offreservation trust land to examine whether an area's location vis-à-vis tribal land per se has an effect on credit limits. Specifically, we use an indicator variable On Tribal Land equal to one when the Census block where an individual resides lies on tribal land (reservation or off- 
reservation trust land) and zero otherwise. The Census block-level share of American Indian population is highly correlated with whether the Census block lies on tribal land or not (the correlation coefficient equals 0.63 ). To examine whether an area's location vis-à-vis the tribal land per se affects credit limits, we therefore also report specifications when we omit the variable measuring the share of American Indians.

We include a full set of reservation and quarter fixed effects. Reservation area fixed effects, where 'reservation area' is the reservation containing or closest to the block of individuals' residence, absorb any reservation-level policies, attitudes, and socio-economic conditions, which might impact credit outcomes. These include, for example, the extent of trust land (see, e.g., Anderson and Lueck 1992, Laderman and Reid 2010, Akee and Jorgensen 2014) and the degree of land ownership fractionation (see, e.g., Russ and Stratmann 2014), tribal culture and governance (see, e.g., Cornell and Kalt 2000, Pickering and Mushinski 2001, Dippel 2014, Akee et al. 2015), the presence or absence of casinos (see, e.g., Evans and Topoleski 2002, Cookson 2010, Anderson 2013), the allocation of jurisdiction over disputes (see, e.g., Parker 2012, Dimitrova-Grajzl et al. 2015, Brown et al. 2015) as well as access to banks and reservation-specific financial lending institutions such as Native Community Development Financial Institutions (Dimitrova-Grajzl et al. 2015). Quarter fixed effects control for any changes in credit and other conditions that vary over time but are common to all areas under consideration, such as business cycle effects. Quarter fixed effects further absorb changes in the price level which allows us to interpret our effects as real (rather than nominal).

\subsection{Estimation Approaches}

Our baseline estimation uses ordinary least squares (OLS). We always log the outcome variables (First Credit Limit or First Ever Credit Limit) to smooth out any effect of outliers and to 
facilitate the interpretation of coefficients as semi-elasticities. We base statistical inference on standard errors that are heteroscedasticity-robust and clustered at the reservation area level to allow for non-zero correlation between error terms for observations associated within the same reservation (but not across reservations). ${ }^{13}$

OLS estimates of the determinants of credit limits as defined by First Credit Limit or First Ever Credit Limit may nevertheless come short of isolating only supply-side considerations if unobserved factors that affect the awarded bankcard credit limit—a decision that is primarily supply-driven - are correlated with unobservable factors that affect whether an individual obtained a bankcard in the first place - an outcome that likely reflects both credit supply and demand. To address this problem, one would ideally be able to separately observe and model the full range of both supply and demand related factors that determine the outcome of whether an individual obtains a bankcard. Data constraints unfortunately preclude us from doing so. Instead, we rely on a more reduced-form approach and use a simple version of Heckman's (1979) two step ('Heckit') procedure that blurs the distinction between supply and demand-driven selection into the sample of individuals who obtain a bankcard. Intuitively, we would expect our reducedform approach to be an adequate representation of a more complete structural model as long as any unobservables that affect the outcome of who obtains a bankcard are conditionally uncorrelated either with our exclusion restrictions (see below) or the amount of awarded credit limits. Despite its potential limitations, the proposed empirical strategy methodologically advances the existing literature that has striven to isolate the supply-side effect of racial neighborhood characteristics on the awarded bankcard credit limits (see Cohen-Cole 2011, Brevoort 2011).

\footnotetext{
${ }^{13}$ In the baseline regressions (see Table 3), we have 161 clusters for the First Credit Limit sample and 161 clusters for the First Ever Credit Limit sample.
} 
Specifically, when First Credit Limit is the outcome of interest, the first step uses a sample of all individual-quarters such that the identified individuals are also observed in the following quarter and, at the same time, the individuals are without a bankcard in the current quarter (or never had a bankcard when First Ever Credit Limit is the outcome of interest). We then estimate a probit of whether an individual obtains a bankcard in the next quarter. We use the resulting estimates to compute the inverse Mills ratio. In the second step, we estimate an OLS regression with either logged First Credit Limit or First Ever Credit Limit as the outcome variable and the estimated inverse Mills ratio from the first step as one of the covariates. ${ }^{14}$ Due to the non-linearity stemming from the inclusion of the inverse Mills ratio among the regressors, the identification of parameters in the second step is formally possible even if the vector of covariates in the second step is identical to the vector of covariates in the first step. Such functional form-based identification, however, can be plagued by severe multicollinearity and, consequently, large standard errors (see, e.g., Wooldridge 2002: 564; Cameron and Trivedi 2005: 551). To obtain more precise parameter estimates, we rely on exclusion restrictions. Specifically, in the first step (probit) we include two additional variables in addition to the full set of covariates discussed in the previous section: a dummy equal to one if the consumer's credit record shows a hard-pull inquiry in the previous, current or next quarter (relative to the quarter in which Equifax Risk Score is measured) and a Census block level measure of bank density.

\footnotetext{
${ }^{14}$ Consider an individual whom we observe for four consecutive quarters with a sequence of bankcard account observations $\{0,0,1,1\}$, where 0 denotes absence of a bankcard account and 1 its presence. Then, this individual contributes two observations to the first stage probit regression. The first observation consists of individual-level controls from the first quarter and a 0 for the binary dependent variable of whether the individual gets a first card next quarter. The second observation consists of individual level control values from the second quarter and a 1 for the dependent variable (since the individual transitions from zero to at least one bankcard in the third quarter). The same individual contributes one observation to the second stage regression consisting of second quarter values of the individual level controls and the third quarter value of logged credit limit for the dependent variable. Note that since the fourth quarter is the second quarter in which this individual has a bankcard, it contributes nothing to either stage.
} 
Industry sources indicate that credit cards are rarely issued without at least one hard inquiry initiated either upon the consumer's own initiative or his/her affirmative response to a credit card solicitation. ${ }^{15}$ The presence of a hard inquiry thus indicates a consumer's desire for credit, but in itself conveys little information about the amount of credit (if any) that a lender will grant upon final review of the consumer's credit history and full credit application. Our measure of hard inquiries is admittedly imperfect, partly because some inquiries are unrelated to credit cards (e.g., for auto loans) and partly because lenders often direct hard inquiries to only a subset of the three major credit bureaus while we rely on data from only one of the three major credit bureaus. This measurement error will tend to reduce, but not eliminate, the power of our hard inquiry dummy to predict whether an individual obtains a bankcard. In sum, both the inquiry dummy and our measure of bank density should predict whether an individual obtains a bankcard, but conditional on getting a new bankcard and after controlling for other covariates should not affect the awarded credit limit, thereby satisfying the exclusion restriction.

\section{Results}

\subsection{Main Results}

Table 3 presents the results. The first four columns show the results with logged First Credit Limit as the outcome variable. The last four columns show the results with logged First Ever Credit Limits as the outcome variable. Columns (1) through (3) and (5) through (7) are based on OLS estimation. Columns (4) and (8) are based on the Heckit approach. The coefficient on the neighborhood racial composition variable (Share American Indian) is negative and statistically significant (using two-sided test of significance) in all four OLS specifications reported in Table

\footnotetext{
${ }^{15}$ See, e.g., https://thescore.vantagescore.com/article/183/uses-credit-scores-prospecting.
} 
3 that include Share American Indian among the explanatory variables (columns (1), (2), (5), and $(6))$.

The Heckit estimates (columns (4) and (8)) are very similar to the corresponding OLS estimates (columns (2) and (6)). The coefficients on the inverse Mills ratios are statistically significantly different from zero, a finding suggesting that sample selection concerns discussed in the previous section are indeed substantiated in the data. The first stages of the corresponding Heckit estimates are reported in Table A2. The coefficient on presence of an inquiry is positive, as anticipated, and statistically very significant. In contrast, our block-level measure of bank density is positive and statistically significant only in the first stage of the First Credit Limit regression. Based on the estimates in column (4), consumers currently without a bankcard who reside in neighborhoods where all residents are American Indians are all else equal on average awarded a 16.2 percent lower total credit limit than consumers who reside in neighborhoods with no American Indian residents. Equivalently, for consumers currently without a bankcard, a one standard deviation increase in Share American Indian is ceteris paribus associated with an approximately 2.1 percent lower awarded total credit limit. Based on the estimates in column (8), our preferred specification, consumers who never previously owned a bankcard and who reside in neighborhoods where all residents are American Indians are on average awarded a 23.6 percent lower total credit limit than consumers who reside in neighborhoods with no American Indian residents, all else equal. Equivalently, for consumers who never previously owned a bankcard, a one standard deviation increase in Share American Indian is ceteris paribus associated with an approximately 3.7 percent lower awarded total credit limit. Our empirical approach is designed to isolate the supply-side from demand-side considerations and mitigate the omitted variable bias. Our evidence therefore raises concerns that lenders in Indian Country may 
discriminate based on neighborhood racial composition. In the absence of an experimental research design, however, it should not be interpreted as conclusive evidence of discrimination. Specifically, the inability to control for individual-level income is likely biasing our estimates downward, rendering the absolute magnitude of the negative effect of Share American Indian greater than it likely truly is. This renders the case for lenders' discrimination based on neighborhood racial characteristics weaker than our point estimates might suggest.

Interestingly, the coefficient on the indicator variable On Tribal Land is never statistically significantly different from zero (see columns (2) through (4) and (6) through (8)). This is true even if we omit controlling for Share American Indian (columns (3) and (7)). We thus do not find evidence that the location of an individual's neighborhood vis-à-vis a reservation or off-reservation trust land has an effect on the awarded bankcard credit limit. ${ }^{16}$

In contrast, the variables capturing an individual's credit history are overall highly statistically significant across all eight specifications reported in Table 3. To interpret the coefficients on the Equifax Risk Score quintile dummies, note that the omitted category is the lowest (first) quintile. Thus, based on specification in column (4) (column (8), respectively), possessing Equifax Risk Score in the second as opposed to the lowest quintile of the Equifax Risk Score distribution is associated with on average a 70 (71) percent increase in total awarded bankcard credit limit, all else equal. Possessing Equifax Risk Score in the highest as opposed to lowest quintile of the Equifax Risk Score distribution is all else equal associated with on average a 1,261 (772) percent increase in total awarded bankcard credit limit.

\footnotetext{
${ }^{16}$ The insignificance of the On Tribal Land variable is consistent with the view that credit card contracts invariably specify a specific state court in which disputes would be heard, thus removing tribal courts from any role in reaching a judgment in consumer-lender disputes. Enforcement of judgments related to unsecured credit, including credit cards, would also typically proceed with limited involvement from tribal courts.
} 
Even after controlling for an individual's Equifax Risk Score, recent history of personal bankruptcy is statistically significantly negatively associated with total awarded credit limit across all specifications in Table 3. Based on the estimates in column (4) (column (8), respectively), having filed for bankruptcy within the last two years is associated with, on average, a 12 (31) percent decrease in the total awarded bankcard credit limit. The negative effect of bankruptcy on the total awarded credit limit is smaller in magnitude, but still statistically significant, if the consumer filed for bankruptcy in the more distant past, between two and ten years ago. ${ }^{17}$ These findings suggest that filing for personal bankruptcy has a lingering effect on an individual's credit limit beyond the effect captured by the Equifax Risk Score.

\subsection{Robustness Checks}

We conducted a number of robustness checks to explore the sensitivity of our results on the effect of neighborhood racial composition. The robustness checks for First Credit Limit regressions are presented in Tables 4 and 5. The results for First Ever Credit Limit as the preferred outcome variable are shown in Tables 6 and 7. We, first, examined whether the effect of Share American Indian on total awarded credit limit is non-linear. To this end we estimated a set of models where Share American Indian is included in the model as a quadratic polynomial (columns (1) and (2) in Tables 4 and 6) and a set of models where we discretize Share American Indian using a full set of indicator variables for quintiles of the distribution (columns (1) and (2) in Tables 5 and 7). We find no evidence of non-linearity of the effect of Share American Indian. Regardless of the outcome variable (First Credit Limit or First Ever Credit Limit), the coefficient on the linear term in the quadratic polynomial specifications is negative and statistically

\footnotetext{
${ }^{17}$ After ten years, personal bankruptcy is no longer part of the credit file.
} 
significant, while the coefficient on the squared Share American Indian is never statistically significantly different from zero. This result obtains regardless of whether we control for an individual's location vis-à-vis tribal land (column (1) of Tables 4 and 6) or not (column (2) of Tables 4 and 6). In the specifications with indicators for quintiles of Share American Indian (columns (1) and (2) of Tables 5 and 7), the only robustly statistically significant coefficient among the coefficients on the indicators for quintiles of Share American Indian is that for the highest (fifth) quintile.

We replaced the indicator variable On Tribal Land with a new indicator variable On Reservation equal to one if and only if an individual resides on a reservation (as opposed to tribal land located off the reservation). The results in column (3) of Tables 4 and 6 demonstrate that this alternative control for an area's location does not change our findings about the effect of Share American Indian. In addition, much like the coefficient on the variable On Tribal Land, the coefficient on the variable On Reservation is statistically insignificantly different from zero regardless of whether we control for Share American Indian (column (3) of Tables 4 and 6) or not (column (4) of Tables 4 and 6).

Instead of controlling for an individual's Equifax Risk Score with the full set of quintiles based on the distribution of the sample in a given year, we controlled for the effect of the Equifax Risk Score by including a third-degree polynomial in this variable. The OLS results in column (5) of Tables 4 and 6 and Heckit results in column (7) of Tables 4 and 6 show that doing so preserves the statistical significance of the coefficient on Share American Indian and barely changes the implied magnitude of the effect.

We controlled for the number of derogatory accounts. The results are reported in column (6) of Tables 4 and 6. The coefficient on Share American Indian continues to be negative and 
statistically significant. The coefficient on the number of derogatory accounts (not reported) is, as expected, negative and statistically significant both when use First Credit Limit (Table 4, column (6)) and when we use First Ever Credit Limit (Table 6, column (6)) as the outcome of interest.

We redefined our Share American Indian variable so that it is measured at the ZIP code level of a rather than the Census block level. We then estimated the model with both OLS and Heckit approach. The results are reported in columns (8) and (9) of Tables 4 and 6. The effect of redefined Share American Indian, albeit somewhat smaller in absolute magnitude, continues to be negative and statistically significant.

We re-estimated our models by dropping outliers, defined as the observations with credit limits in the top and bottom one percent of all credit limits in our sample. The OLS and Heckit results based on specifications analogous to those featured in columns (2) and (4) of Table 3 are reported in columns (3) and (4) of Table 5 for First Credit Limit sample, and in columns (3) and (4) of Table 7 for the First Ever Credit Limit sample. We restricted our sample to observations that feature a hard-pull inquiry in either the quarter of the credit limit award or either of the previous two quarters. The results are reported in column (5) of Tables 5 and 7 . We estimated a model in which we measure credit limit in the same quarter as the Equifax Risk Score and the other individual level variables. Since Equifax Risk Score is virtually never missing in the same quarter that an individual has a credit limit, doing so increases sample size by including individuals with an observed value for First Credit Limit (Table 5) or First Ever Credit Limit (Table 7) who were either observed in the previous quarter but were missing the Equifax Risk Score or were simply not observed in the previous quarter. The results are reported in column (6) 
of Tables 5 and 7. In all of these robustness checks, the coefficient on Share American Indian continues to be negative and statistically significant.

Finally, we examined if our results are perhaps driven by a subset of our observations. To this end, we focused on our preferred outcome variable First Ever Credit Limit and first reestimated the OLS model (6) and Heckit model (8) from Table 3 while one by one dropping all consumers located in each of the ten states with the greatest number of observations in our estimating sample. Table 8 summarizes the results. The coefficient on Share American Indian remains negative and statistically significant in each of the regressions. These findings suggest that the results discussed in Section 4.1 are not driven by a specific geography.

\section{Conclusion}

We examine whether persistent concerns about lenders' discrimination based on neighborhood racial characteristics and the resulting lack of access to, and usage of, bankcard credit in minority communities in the United States can be empirically substantiated in the thus far unexplored context of Indian Country. To this end we draw on individual credit histories available in the Federal Reserve Bank of New York/Equifax Consumer Credit Panel (CCP) and Census data on neighborhood characteristics. Utilizing multiple approaches aimed at isolating supply from demand considerations, we find that residing in an Indian Country neighborhood with a large share of American Indian residents is all else equal associated with lower total awarded bankcard credit limit than is residing in an Indian Country neighborhood with a small share of American Indian residents. In contrast, the location of an individual's neighborhood vis-à-vis a reservation or off-reservation trust land exhibits no effect on bankcard credit outcomes.

Therefore, the interpretation of our findings is that they are consistent with the possibility that lenders in Indian Country discriminate based on neighborhood racial composition, but not 
conclusive evidence thereof. To shed further light on this important policy question in the absence of a true experimental setting, future research will need to draw on even more detailed data. In particular, information about individual income, which we proxy with Census block group-level measure of income, and contractual terms of the credit relationship, such as the interest rate, fees, and other terms of debt repayment, would together with bankcard credit demand-specific variables facilitate an even cleaner identification of the structural parameters of bankcard credit supply, and a clearer resolution of the possibility of discrimination.

Our empirical results imply that individuals' Equifax Risk Score and recent history of bankruptcy are robust predictors of bankcard credit outcomes. Indeed, according to our estimates, consumers who raise their scores even by relatively moderate amounts can be expected to increase the awarded credit limits by a significantly larger extent than predicted by a hypothetical move from an Indian Country neighborhood with a high share of American Indian residents to an Indian Country neighborhood with a low share of American Indian residents. This suggests that financial education and credit counseling (see, e.g., Brown et al. 2014) -services often provided by community development financial institutions and other community service organizations in tribal communities - are important for improving bankcard credit access and usage on and near reservations. 


\section{References}

Akee, Randall and Miriam Jorgensen. 2014. "Property Institutions and Business Investment on American Indian Reservations." Regional Science and Urban Economics, 46, 116-125.

Akee, Randall, Miriam Jorgensen, and Uwe Sunde. 2015. "Constitutions and Economic Development: Evidence from the American Indian Nations." Journal of Comparative Economics, 43:3, 844-861.

Anderson, Robin J. 2013. "Tribal Casino Impacts on American Indians Well-Being: Evidence from Reservation-Level Census Data." Contemporary Economic Policy, 31:2, 291-300.

Anderson, Terry L. and Dean Lueck. 1992. "Land Tenure and Agricultural Productivity on Indian Reservations." Journal of Law and Economics, 35:2, 427-454.

Avery, Robert B., Kenneth P. Brevoort, and Glenn B. Canner. 2010. "Does Credit Scoring Produce a Disparate Impact?" Board of Governors of the Federal Reserve System, Finance and Economics Discussion Series, Working Paper No. 2010-58.

Bertaut, Carol C. and Michael Haliassos. 2006. "Credit Cards: Facts and Theories." In: Bertola, Guisseppe, Richard Disney, and Charles Grant (Eds.), The Economics of Consumer Credit. Cambridge, MA: MIT Press, 181-237.

Blanchflower, David G., Phillip B. Levine, and David J. Zimmerman. 2003. "Discrimination in the Small-Business Credit Market." Review of Economics and Statistics, 85:4, 930-943.

Board of Governors of the Federal Reserve System. 2007. Report to the Congress on Credit Scoring and Its Effects on the Availability and Affordability of Credit.

Brevoort, Kenneth P. 2011. "Credit Card Redlining Revisited." Review of Economics and Statistics, 93:2, 714-724.

Bricker, Jesse and Lisa J. Dettling, Alice Henriques, Joanne W. Hsu, Kevin B. Moore, John Sabelhaus, Jeffrey Thompson, and Richard A. Windle. 2014. "Changes in U.S. Family Finances from 2010 to 2013: Evidence from the Survey of Consumer Finances." Federal Reserve Bulletin 100:4, 1-41.

Brown, James R., Anthony Cookson, and Rawley Z. Heimer. 2015. "Law and Finance Matter: Lessons from Externally Imposed Courts." SSRN Working Paper No. 2448091.

Brown, Alexandra, J. Michael Collins, Maximilian Schmeiser, and Carly Urban. 2014. "State Mandated Financial Education and the Credit Behavior of Young Adults." Board of Governors of the Federal Reserve System, Finance and Economics Discussion Series, Working Paper No. 2014-68

Cameron, A. Colin and Pravin K. Trivedi. 2005. Microeconometrics, Methods and Applications. London: Cambridge University Press.

Campbell, Randall, Brandon Roberts, and Kevin Rogers. 2008. "An Evaluation of Lender Redlining in the Allocation of Unsecured Consumer Credit in the US." Urban Studies, 45, 1243.

Chatterjee, Satyajit, Dean Corbae, Makoto Nakajima, and José-Víctor Ríos-Rull. 2007. "A Quantitative Theory of Unsecured Consumer Credit with Risk of Default." Econometrica, 75:6, 1525-1589. 
Clarkson, Gavin. 2009. "Accredited Indians: Increasing the Flow of Private Equity into Indian Country as a Domestic Emerging Market." University of Colorado Law Review, 80:2, 285326.

Cohen-Cole, Ethan. 2011. "Credit Card Redlining." Review of Economics and Statistics, 93:2, 700-713.

Coibion, Olivier and Yuriy Gorodnichenko, Marianna Kudlyak, and John Mondragon. 2014. "Does Greater Inequality Lead to More Household Borrowing? New Evidence from Household Data." NBER Working Paper No. 19850.

Community Development Financial Institutions Fund. 2001. The Report of the Native American Lending Study. U.S. Department of the Treasury, Washington, DC.

Cookson, J. Anthony. 2010. "Institutions and Casinos on American Indian Reservations: An Empirical Analysis of the Location of Indian Casinos." Journal of Law and Economics, 53:4, 651-687.

Cornell, Stephen and Joseph P. Kalt. 1992. "Reloading the Dice: Improving the Chances for Economic Development on American Indian Reservations." In: Cornell, Stephen and Joseph P. Kalt (Eds.), What Can Tribes Do? Strategies and Institutions in American Indian Economic Development, Los Angeles, CA: American Indian Studies Center, 2-51.

Cornell, Stephen and Joseph P. Kalt. 2000. "Where's the Glue? Institutional and Cultural Foundations of American Indian Economic Development." Journal of Socio-Economics, 29:5, 443-470.

Debbaut, Peter, Andra Ghent, and Marianna Kudlyak. 2014. "Are Young Borrowers Bad Borrowers? Evidence from the Credit CARD Act of 2009." Federal Reserve Bank of Richmond Working Paper 13-09R.

Dimitrova-Grajzl, Valentina, Peter Grajzl, A. Joseph Guse, and Richard M. Todd. 2015. "Consumer Credit on American Indian Reservations." Economic Systems, 39:3, 518-540.

Dippel, Christian. 2014. "Forced Coexistence and Economic Development: Evidence from Native American Reservations." Econometrica, 82:6, 2131-2165.

Dymski, Gary A. 2006. "Discrimination in the Credit and Housing Markets: Findings and Challenges." In: Rodgers, William M. III (ed.), Handbook on the Economics of Discrimination, Cheltenham, UK: Edward Elgar, 215-259.

Evans, William N. and Julie Topoleski. 2002. "The Social and Economic Impact of Native American Casinos." NBER Working Paper 9198.

Firestone, Simon. 2014. "Race, Ethnicity, and Credit Card Marketing." Journal of Money, Credit, and Banking, 46:6, 1205-1224.

Gross, David B. and Nicholas S. Souleles. 2002a. "Do Liquidity Constraints and Interest Rates Matter for Consumer Behavior? Evidence from Credit Card Data." Quarterly Journal of Economics, 117:1, 149-185.

Gross, David B., and Nicholas S. Souleles. 2002b. "An Empirical Analysis of Personal Bankruptcy and Delinquency." Review of Financial Studies, 15:1, 319-347.

Han, Song, Benjamin J. Keys, and Geng Li. 2013. "Unsecured Credit Supply over the Credit Cycle: Evidence from Credit Card Mailings." Board of Governors of the Federal Reserve System, Finance and Economics Discussion Paper Series, Working Paper No. 2011-29. 
Heckman, James J. 1979. "Sample Selection Bias as a Specification Error." Econometrica, 47:1, 153-161.

Jambulapati, Vikram and Joanna Stavins. 2014. "Credit CARD Act of 2009: What did banks do?" Journal of Banking and Finance, 46, 21-30.

Jorgensen, Miriam. 2007. Rebuilding Native Nations: Strategies for Governance and Development. Tucson, AZ: The University of Arizona Press.

Ladd, Helen F. 1998. "Evidence on Discrimination in Mortgage Lending." Journal of Economic Perspectives, 12:2, 41-62.

Laderman, Elizabeth and Carolina Reid. 2010. "Mortgage Lending on Native American Reservations: Does a Guarantee Matter?" Journal of Housing Economics, 19, 233-242.

Larrimore, Jeff, Mario Arthur-Bentil, Sam Dodini, and Logan Thomas. 2015. "Report on the Economic Well-Being of U.S. Households in 2014." Board of Governors of the Federal Reserve System.

Lee, Donghoon and Wilbert van der Klaauw. 2010. "An Introduction to the FRBNY Consumer Credit Panel." Federal Reserve Bank of New York Staff Report no. 479.

Native Nations Institute. 2016. Access to Capital and Credit in Native Communities. Tucson, AZ: Native Nations Institute.

Parker, Dominic P. 2012. "The Effects of Legal Institutions on Access to Credit: Evidence from American Indian Reservations." Unpublished manuscript.

Pickering, Kathleen and David Mushinski. 2001. "Making the Case for Culture in Economic Development: A Cross-Section Analysis of Western Tribes." Journal of Economic Issues, 25:1, 45-64.

Pickering, Kathleen, and Mushinski, David. 1999. "Access to Credit on the Pine Ridge Indian Reservation: Banks, Alternative Sources of Credit, and the Lakota Fund." Colorado State University Working Paper.

Pommersheim, Frank. 1989. "The Reservation as Place: A South Dakota Essay." South Dakota Law Review, 34, 246-270.

Russ, Jake and Thomas Stratmann. 2014. "Creeping Normalcy: Fractionation of Indian Land Ownership." CESifo Working Paper No. 4607.

Schuh, Scott and Joanna Stavins. 2014. "The 2011 and 2012 Surveys of Consumer Payment Choice." Federal Reserve Bank of Boston Research Data Report No. 14-1.

Skanderson, David and Dubravka Ritter. 2014. "Fair Lending Analysis of Credit Cards." Federal Reserve Bank of Philadelphia, Payment Cards Center Discussion Paper.

Tootell, Geoffrey M.B. 1996. "Redlining in Boston: Do Mortgage Lenders Discriminate Against Neighborhoods?" Quarterly Journal of Economics, 111:4, 1049-1079.

Wardrip, Keith and Robert M. Hunt. 2013. "Residential Migration, Entry, and Exit as Seen through the Lens of Credit Bureau Data." Federal Reserve Bank of Philadelphia, Community Development Studies and Education Discussion Paper No. 13-01.

Wooldridge, Jeffrey M. 2002. Econometric Analysis of Cross Section and Panel Data. Cambridge, MA: MIT Press. 
Table 1: Variable Description for Key Variables

\begin{tabular}{|c|c|c|c|}
\hline \multicolumn{4}{|c|}{ Panel A: Outcome Variables } \\
\hline Variable & Description & Unit of observation & Source \\
\hline First Credit Limit & $\begin{array}{l}\text { Next quarter's total credit limit (in USD) on all bankcards for individuals currently without a } \\
\text { bankcard. }\end{array}$ & Individual & $\mathrm{CCP}$ \\
\hline First Ever Credit Limit & $\begin{array}{l}\text { Next quarter's total credit limit (in USD) on all bankcards for individuals who have never had } \\
\text { a bankcard. }\end{array}$ & Individual & $\mathrm{CCP}$ \\
\hline Gets First Card Next Quarter & $\begin{array}{l}\text { Indicator variable equal to } 1 \text { if the individual transitions from zero bankcards in the current } \\
\text { quarter to one or more bankcards and a strictly positive credit limit in the next quarter, and } 0 \\
\text { otherwise. Dependent variable in first stage (probit) of Heckit regressions. }\end{array}$ & Individual & $\mathrm{CCP}$ \\
\hline \multicolumn{4}{|c|}{ Panel B: Key Explanatory Variables } \\
\hline Variable & Description & Unit of observation & Source \\
\hline Share American Indian & $\begin{array}{l}\text { Percent of population (aged } 18 \text { or over) that identifies as American Indian either as single race } \\
\text { or in part. }\end{array}$ & Census block & $\begin{array}{l}\text { Census 2000, Summary } \\
\text { File 1, Table P5 }\end{array}$ \\
\hline On Tribal Land & $\begin{array}{l}\text { Indicator variable equal to } 1 \text { if the Census block where the individual resides lies on tribal } \\
\text { land (reservation or off-reservation trust land), and } 0 \text { otherwise. }\end{array}$ & Census block & Census 2000, TIGER \\
\hline On Reservation & $\begin{array}{l}\text { Indicator variable equal to } 1 \text { if the Census block where the individual resides lies within the } \\
\text { boundaries of a reservation, and } 0 \text { otherwise. }\end{array}$ & Census block & Census 2000, TIGER \\
\hline ERS & Equifax Risk Score. & Individual & $\mathrm{CCP}$ \\
\hline Bankruptcy Last 10 Years & $\begin{array}{l}\text { Indicator variable equal to } 1 \text { if individual filed for any type of bankruptcy within the last ten } \\
\text { years, and } 0 \text { otherwise. }\end{array}$ & Individual & $\mathrm{CCP}$ \\
\hline Bankruptcy Last 2 Years & $\begin{array}{l}\text { Indicator variable equal to } 1 \text { if individual filed for any type of bankruptcy within the last two } \\
\text { years, and } 0 \text { otherwise. }\end{array}$ & Individual & $\mathrm{CCP}$ \\
\hline Derogatory Accounts & $\begin{array}{l}\text { Number of accounts with any of the following at any point in time: repossession, charge off, } \\
\text { foreclosure, bankruptcy, internal collection, defaulted student loan. }\end{array}$ & Individual & $\mathrm{CCP}$ \\
\hline Inquiry & $\begin{array}{l}\text { Indicator variable equal to } 1 \text { if there is at least one hard-pull (borrower-initiated) inquiry made } \\
\text { for any reason to Equifax in the previous quarter, current quarter (in which ERS is measured) } \\
\text { or next quarter (in which credit limit is measured), and } 0 \text { otherwise. }\end{array}$ & Individual & $\mathrm{CCP}$ \\
\hline Bank Density & $\begin{array}{l}\text { Number of U.S. bank branches per square mile within ten miles }(16 \mathrm{~km}) \text { of the center of the } \\
\text { census block in the current calendar year. }\end{array}$ & Census block & FDIC \\
\hline
\end{tabular}


Table 2: Descriptive Statistics for Key Variables

\begin{tabular}{|c|c|c|c|c|c|}
\hline \multicolumn{6}{|c|}{ Panel A: First Credit Limit sample (see Table 3) } \\
\hline Variable & No. Obs. & Mean & Std. Dev. & Min. & Max. \\
\hline \multicolumn{6}{|l|}{ Census block level } \\
\hline Share American Indian & 84,023 & 0.039 & 0.120 & 0 & 1 \\
\hline On Tribal Land & 84,023 & 0.039 & 0.194 & 0 & 1 \\
\hline On Reservation & 75,553 & 0.043 & 0.204 & 0 & 1 \\
\hline \multicolumn{6}{|l|}{ ZIP code level } \\
\hline Share American Indian & 81,643 & 0.043 & 0.111 & 0 & 0.996 \\
\hline \multicolumn{6}{|l|}{ Individual level } \\
\hline First Credit Limit & 84,023 & $2,641.3$ & $5,333.1$ & 1 & 368,000 \\
\hline Equifax Risk Score (ERS) & 84,023 & 645.5 & 73.9 & 318 & 841 \\
\hline Bankruptcy Last 10 Years & 84,023 & 0.138 & 0.345 & 0 & 1 \\
\hline Bankruptcy Last 2 Years & 84,023 & 0.056 & 0.230 & 0 & 1 \\
\hline Derogatory Accounts & 84,023 & 1.24 & 2.50 & 0 & 44 \\
\hline Age & 84,023 & 36.2 & 13.2 & 18 & 70 \\
\hline Gets First Card Next Quarter & $2,461,363$ & 0.034 & 0.182 & 0 & 1 \\
\hline Inquiry & $2,461,363$ & 0.515 & 0.500 & 0 & 1 \\
\hline Bank Density & $2,461,363$ & 0.281 & 0.251 & 0 & 1.197 \\
\hline \multicolumn{6}{|c|}{ Panel B: First Ever Credit Limit sample (see Table 3) } \\
\hline Variable & No. Obs. & Mean & Std. Dev. & Min. & Max. \\
\hline \multicolumn{6}{|l|}{ Census block level } \\
\hline Share American Indian & 34,413 & 0.046 & 0.137 & 0 & 1 \\
\hline On Tribal Land & 34,413 & 0.046 & 0.210 & 0 & 0 \\
\hline On Reservation & 31,077 & 0.051 & 0.219 & 0 & 0 \\
\hline \multicolumn{6}{|l|}{ ZIP code level } \\
\hline Share American Indian & 33,495 & 0.049 & 0.137 & 0 & 0.996 \\
\hline \multicolumn{6}{|l|}{ Individual level } \\
\hline First Ever Credit Limit & 34,413 & 1616.7 & 3173.6 & 1 & 200,000 \\
\hline Equifax Risk Score (ERS) & 34,413 & 636.0 & 60.3 & 318 & 822 \\
\hline Bankruptcy Last 10 Years & 34,413 & 0.056 & 0.229 & 0 & 1 \\
\hline Bankruptcy Last 2 Years & 34,413 & 0.017 & 0.129 & 0 & 1 \\
\hline Derogatory Accounts & 34,413 & 0.414 & 1.23 & 0 & 32 \\
\hline Age & 34,413 & 31.4 & 12.5 & 18 & 70 \\
\hline Gets First Card Next Quarter & $1,205,552$ & 0.029 & 0.167 & 0 & 1 \\
\hline Inquiry & $1,205,552$ & 0.519 & 0.500 & 0 & 1 \\
\hline Bank Density & $1,205,552$ & 0.276 & .251 & 0 & 1.197 \\
\hline
\end{tabular}

Notes: Equifax Risk Score (ERS) is the raw Equifax's proprietary credit risk score indicating default risk; it ranges from 280 and 850 with lower scores correspond to higher estimated risk of default. Age is consumer's age in years. Computed using data from the Federal Reserve Bank of New York/Equifax Consumer Credit Panel. 
Table 3: Baseline Regression Results

\begin{tabular}{|c|c|c|c|c|c|c|c|c|}
\hline \multirow[b]{2}{*}{ Explanatory Variables } & \multicolumn{4}{|c|}{ First Credit Limit } & \multicolumn{4}{|c|}{ First Ever Credit Limit } \\
\hline & $(1)$ & (2) & (3) & (4) & $(5)$ & $(6)$ & (7) & $(8)$ \\
\hline \multicolumn{9}{|l|}{ Census block level } \\
\hline Share American Indian & $\begin{array}{c}-0.173 * * * \\
(0.042)\end{array}$ & $\begin{array}{c}-0.174 * * \\
(0.053)\end{array}$ & & $\begin{array}{c}-0.177 * * * \\
(0.050)\end{array}$ & $\begin{array}{c}-0.221 * * \\
(0.066)\end{array}$ & $\begin{array}{c}-0.262 * * * \\
(0.078)\end{array}$ & & $\begin{array}{c}-0.269 * * * \\
(0.072)\end{array}$ \\
\hline On Tribal Land & & $\begin{array}{c}0.001 \\
(0.029)\end{array}$ & $\begin{array}{l}-0.039 \\
(0.022)\end{array}$ & $\begin{array}{c}0.001 \\
(0.028)\end{array}$ & & $\begin{array}{c}0.042 \\
(0.044)\end{array}$ & $\begin{array}{l}-0.030 \\
(0.038)\end{array}$ & $\begin{array}{c}0.043 \\
(0.042)\end{array}$ \\
\hline \multicolumn{9}{|l|}{ Individual level } \\
\hline ERS 2 ${ }^{\text {nd }}$ Quintile & $\begin{array}{c}0.515 * * * \\
(0.022)\end{array}$ & $\begin{array}{c}0.515 * * * \\
(0.022)\end{array}$ & $\begin{array}{c}0.518^{* * * *} \\
(0.021)\end{array}$ & $\begin{array}{c}0.533 * * * \\
(0.013)\end{array}$ & $\begin{array}{c}0.478^{* * * *} \\
(0.026)\end{array}$ & $\begin{array}{c}0.478^{* * *} \\
(0.026)\end{array}$ & $\begin{array}{c}0.482 * * * \\
(0.025)\end{array}$ & $\begin{array}{c}0.534 * * * \\
(0.021)\end{array}$ \\
\hline ERS $3^{\text {rd }}$ Quintile & $\begin{array}{c}1.418 * * * \\
(0.017)\end{array}$ & $\begin{array}{c}1.418^{* * *} \\
(0.018)\end{array}$ & $\begin{array}{c}1.423 * * * \\
(0.017)\end{array}$ & $\begin{array}{c}1.441 * * * \\
(0.014)\end{array}$ & $\begin{array}{c}1.159 * * * \\
(0.024)\end{array}$ & $\begin{array}{c}1.159 * * * \\
(0.024)\end{array}$ & $\begin{array}{c}1.165^{* * * *} \\
(0.023)\end{array}$ & $\begin{array}{c}1.224^{* * *} \\
(0.023)\end{array}$ \\
\hline ERS $4^{\text {th }}$ Quintile & $\begin{array}{c}2.263 * * * \\
(0.020)\end{array}$ & $\begin{array}{c}2.263^{* * *} \\
(0.020)\end{array}$ & $\begin{array}{c}2.269 * * * \\
(0.019)\end{array}$ & $\begin{array}{c}2.282 * * * \\
(0.017)\end{array}$ & $\begin{array}{c}1.890^{* * *} \\
(0.028)\end{array}$ & $\begin{array}{c}1.891^{* * *} \\
(0.028)\end{array}$ & $\begin{array}{c}1.899^{* * *} \\
(0.029)\end{array}$ & $\begin{array}{c}1.935^{* * *} \\
(0.032)\end{array}$ \\
\hline ERS $5^{\text {th }}$ Quintile & $\begin{array}{c}2.597 * * * \\
(0.021)\end{array}$ & $\begin{array}{c}2.597 * * * \\
(0.021)\end{array}$ & $\begin{array}{c}2.605 * * * \\
(0.021)\end{array}$ & $\begin{array}{c}2.611 * * * \\
(0.023)\end{array}$ & $\begin{array}{c}2.153 * * * \\
(0.067)\end{array}$ & $\begin{array}{c}2.155^{* * *} \\
(0.067)\end{array}$ & $\begin{array}{c}2.161 * * * \\
(0.068)\end{array}$ & $\begin{array}{c}2.166 * * * \\
(0.083)\end{array}$ \\
\hline Bankruptcy Last 10 Years & $\begin{array}{c}-0.262 * * * \\
(0.020)\end{array}$ & $\begin{array}{c}-0.262 * * * \\
(0.020)\end{array}$ & $\begin{array}{c}-0.260 * * * \\
(0.020)\end{array}$ & $\begin{array}{c}-0.026^{* * *} \\
(0.015)\end{array}$ & $\begin{array}{c}-0.372 * * * \\
(0.040)\end{array}$ & $\begin{array}{c}-0.371 * * * \\
(0.040)\end{array}$ & $\begin{array}{c}-0.371 * * * \\
(0.040)\end{array}$ & $\begin{array}{c}-0.366 * * * \\
(0.032)\end{array}$ \\
\hline Bankruptcy Last 2 Years & $\begin{array}{c}-0.114 * * * \\
(0.030)\end{array}$ & $\begin{array}{c}-0.114^{* * * *} \\
(0.030)\end{array}$ & $\begin{array}{c}-0.114 * * * \\
(0.030)\end{array}$ & $\begin{array}{c}-0.103 * * * \\
(0.022)\end{array}$ & $\begin{array}{l}-0.032 \\
(0.042)\end{array}$ & $\begin{array}{l}-0.032 \\
(0.043)\end{array}$ & $\begin{array}{l}-0.032 \\
(0.043)\end{array}$ & $\begin{array}{l}-0.009 \\
(0.056)\end{array}$ \\
\hline Age cohort effects & Yes & Yes & Yes & Yes & Yes & Yes & Yes & Yes \\
\hline Census block group level & & & & & & & & \\
\hline Socio-Economic Controls & Yes & Yes & Yes & Yes & Yes & Yes & Yes & Yes \\
\hline Reservation FE & Yes & Yes & Yes & Yes & Yes & Yes & Yes & Yes \\
\hline $\begin{array}{l}\text { Quarter FE } \\
\text { Inverse Mills Ratio }\end{array}$ & Yes & Yes & Yes & $\begin{array}{c}\text { Yes } \\
0.053^{* *} \\
(0.017)\end{array}$ & Yes & Yes & Yes & $\begin{array}{c}\text { Yes } \\
0.136^{* * *} \\
(0.027)\end{array}$ \\
\hline R-squared & 0.3662 & 0.3662 & 0.3659 & & 0.2175 & 0.2175 & 0.2169 & \\
\hline No. obs. & 84,023 & 84,023 & 84,023 & 84,023 & 34,413 & 34,413 & 34,413 & 34,413 \\
\hline
\end{tabular}

Notes: The outcome variable is logged First Credit Limit in columns (1)-(4) and logged First Ever Credit Limit in columns (5)-(8). Columns (1)-(3) and (5)-(7) present results based on OLS regressions. Columns (4) and (8) present results using Heckman's (1979) two-step approach, where the exclusion restrictions are an indicator for recent hard inquiry and a measure of bank density. Reported standard errors are heteroscedasticity-robust and clustered at reservation level. *, **, and *** indicate significance at the $5 \%, 1 \%$ and $0.1 \%$ levels, respectively. Computed using data from the Federal Reserve Bank of New York/Equifax Consumer Credit Panel. 
Table 4: Robustness Checks, First Credit Limit

\begin{tabular}{|c|c|c|c|c|c|c|c|c|c|}
\hline Explanatory Variables & (1) & $(2)$ & (3) & (4) & $(5)$ & (6) & (7) & (8) & (9) \\
\hline Share American Indian (block level) & $\begin{array}{c}-0.345^{* *} \\
(0.123)\end{array}$ & $\begin{array}{c}-0.348^{* *} \\
(0.121)\end{array}$ & $\begin{array}{c}-0.166^{* *} \\
(0.054)\end{array}$ & & $\begin{array}{c}-0.148^{* *} \\
(0.053)\end{array}$ & $\begin{array}{c}-0.176^{* *} \\
(0.053)\end{array}$ & $\begin{array}{l}0.149 * * \\
(0.049)\end{array}$ & & \\
\hline Share American Indian (block level)-squared & $\begin{array}{c}0.216 \\
(0.134)\end{array}$ & $\begin{array}{c}0.215 \\
(0.133)\end{array}$ & & & & & & & \\
\hline Share American Indian (ZIP code level) & & & & & & & & $\begin{array}{l}-0.118^{*} \\
(0.050)\end{array}$ & $\begin{array}{l}-0.121^{+} \\
(0.066)\end{array}$ \\
\hline On Tribal Land & $\begin{array}{l}-0.004 \\
(0.030)\end{array}$ & & & & $\begin{array}{c}0.011 \\
(0.030)\end{array}$ & $\begin{array}{c}0.002 \\
(0.029)\end{array}$ & $\begin{array}{c}0.011 \\
(0.028)\end{array}$ & $\begin{array}{l}-0.019 \\
(0.026)\end{array}$ & $\begin{array}{l}-0.020 \\
(0.028)\end{array}$ \\
\hline On Reservation & & & $\begin{array}{c}0.002 \\
(0.029)\end{array}$ & $\begin{array}{l}-0.037 \\
(0.023)\end{array}$ & & & & & \\
\hline $\begin{array}{l}\text { ERS quintiles } \\
\text { ERS polynomial }\end{array}$ & Yes & Yes & Yes & Yes & Yes & Yes & Yes & Yes & Yes \\
\hline $\begin{array}{l}\text { Bankruptcy controls } \\
\text { Derogatory Accounts control }\end{array}$ & Yes & Yes & Yes & Yes & Yes & $\begin{array}{l}\text { Yes } \\
\text { Yes }\end{array}$ & Yes & Yes & Yes \\
\hline Age cohort effects & Yes & Yes & Yes & Yes & Yes & Yes & Yes & Yes & Yes \\
\hline Census block group socio-econ controls & Yes & Yes & Yes & Yes & Yes & Yes & Yes & Yes & Yes \\
\hline $\begin{array}{l}\text { Reservation and quarter FE } \\
\text { Inverse Mills Ratio }\end{array}$ & Yes & Yes & Yes & Yes & Yes & Yes & $\begin{array}{c}\text { Yes } \\
0.016 \\
(0.017)\end{array}$ & Yes & $\begin{array}{c}\text { Yes } \\
0.054^{* *} \\
(0.018)\end{array}$ \\
\hline R-squared & 0.3663 & 0.3663 & 0.3623 & 0.3621 & 0.3893 & 0.3667 & & 0.3660 & \\
\hline No. obs. & 84,023 & 84,023 & 75,553 & 75,553 & 84,023 & 84,023 & 84,023 & 81,643 & 81,643 \\
\hline
\end{tabular}

Notes: The outcome variable is logged First Credit Limit. Columns (1)-(6) and (8) present results based on OLS regressions. Columns (7) and (9) present results using Heckman's

(1979) two-step approach, where the exclusion restrictions are an indicator for recent hard inquiry and a measure of bank density. In Columns (1) and (2), Census block group socioeconomic controls include squared terms for Share Black and Share Hispanic. In Columns (3) and (4), the geographic sample is restricted to areas within 16 km of a reservation, as opposed to areas with $16 \mathrm{~km}$ of any federally recognized tribal land (reservation or off-reservation trust lands). In Columns (8) and (9), sample sizes are reduced due to imperfect matching of postal zip-codes from credit data and zip-code tabulation areas from census data. Reported standard errors are heteroscedasticity-robust and clustered at reservation level. $+, *, * *$, and $* * *$ indicate significance at the $10 \%, 5 \%, 1 \%$, and $0.1 \%$ levels, respectively. Computed using data from the Federal Reserve Bank of New York/Equifax Consumer Credit Panel. 
Table 5: Further Robustness Checks, First Credit Limit

\begin{tabular}{|c|c|c|c|c|c|c|}
\hline Explanatory Variables & $(1)$ & $(2)$ & (3) & (4) & 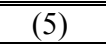 & $(6)$ \\
\hline Share American Indian (block level) & & & $\begin{array}{c}-0.146^{* *} \\
(0.051)\end{array}$ & $\begin{array}{c}-0.149 * * \\
(0.047)\end{array}$ & $\begin{array}{l}-0.098^{+} \\
(0.053)\end{array}$ & $\begin{array}{c}-0.141 * * * \\
(0.042)\end{array}$ \\
\hline Share American Indian $2^{\text {nd }}$ Quintile & $\begin{array}{c}-0.018 \\
(0.035)\end{array}$ & $\begin{array}{c}-0.018 \\
(0.036)\end{array}$ & & & & \\
\hline Share American Indian $3^{\text {rd }}$ Quintile & $\begin{array}{c}0.012 \\
(0.048)\end{array}$ & $\begin{array}{c}0.010 \\
(0.061)\end{array}$ & & & & \\
\hline Share American Indian $4^{\text {th }}$ Quintile & $\begin{array}{l}-0.016 \\
(0.087)\end{array}$ & $\begin{array}{c}-0.018 \\
(0.081)\end{array}$ & & & & \\
\hline Share American Indian $5^{\text {th }}$ Quintile & $\begin{array}{l}-0.100^{+} \\
(0.052)\end{array}$ & $\begin{array}{l}-0.102 * \\
(0.051)\end{array}$ & & & & \\
\hline On Tribal Land & Yes & Yes & Yes & Yes & Yes & Yes \\
\hline ERS quintiles & Yes & Yes & Yes & Yes & Yes & Yes \\
\hline Bankruptcy controls & Yes & Yes & Yes & Yes & Yes & Yes \\
\hline Derogatory Accounts control & & & & Yes & & \\
\hline Age cohort effects & Yes & Yes & Yes & Yes & Yes & Yes \\
\hline Census block group socio-econ controls & Yes & Yes & Yes & Yes & Yes & Yes \\
\hline Reservation and quarter FE & Yes & Yes & Yes & Yes & Yes & Yes \\
\hline Inverse Mills Ratio & & $\begin{array}{c}0.054^{* *} \\
(0.017)\end{array}$ & & $\begin{array}{c}0.045^{* *} \\
(0.017)\end{array}$ & & \\
\hline R-squared & 0.3661 & & 0.3685 & & 0,3380 & 0.3743 \\
\hline No. obs. & 84,023 & 84,023 & 82,361 & 82,361 & 68,216 & 118,317 \\
\hline
\end{tabular}

Notes: The outcome variable is logged First Credit Limit. Columns (1), (3), (5), and (6) present results based on OLS regressions. Columns (2) and (4) present results using Heckman's (1979) two-step approach, where the exclusion restrictions are an indicator for recent hard inquiry and a measure of bank density. Columns (3) and (4) exclude the top and bottom one percent of new credit limits. In column (5), sample is restricted to individuals for whom Equifax recorded a hard inquiry either in the quarter they acquired the new bankcard or the previous two quarters. In column (6), ERS is measured in the same quarter as the First Credit Limit; to this end, the definition of First Credit Limit is expanded to include credit limits for individuals who either did not appear in previous quarter or whose ERS was missing in previous quarter. Reported standard errors are heteroscedasticity-robust and clustered at reservation level. $+, *, * *$, and *** indicate significance at the $10 \%, 5 \%, 1 \%$, and $0.1 \%$ levels, respectively. Computed using data from the Federal Reserve Bank of New York/Equifax Consumer Credit Panel. 
Table 6: Robustness Checks, First Ever Credit Limit

\begin{tabular}{|c|c|c|c|c|c|c|c|c|c|}
\hline Explanatory Variables & (1) & $(2)$ & (3) & (4) & $(5)$ & (6) & $(7)$ & $(8)$ & (9) \\
\hline Share American Indian (block level) & $\begin{array}{l}-0.374 * \\
(0.189)\end{array}$ & $\begin{array}{l}-0.344^{+} \\
(0.188)\end{array}$ & $\begin{array}{c}-0.246 * * * \\
(0.076)\end{array}$ & & $\begin{array}{c}-0.254 * * * \\
(0.078)\end{array}$ & $\begin{array}{c}-0.264^{* *} \\
(0.080)\end{array}$ & $\begin{array}{c}-0.258 * * * \\
(0.071)\end{array}$ & & \\
\hline Share American Indian (block level)-squared & $\begin{array}{l}0.139 \\
(0.193)\end{array}$ & $\begin{array}{c}0.149 \\
(0.192)\end{array}$ & & & & & & & \\
\hline Share American Indian (ZIP code level) & & & & & & & & $\begin{array}{l}-0.192 * \\
(0.081)\end{array}$ & $\begin{array}{l}-0.193 * \\
(0.095)\end{array}$ \\
\hline On Tribal Land & $\begin{array}{c}0.039 \\
(0.045)\end{array}$ & & & & $\begin{array}{c}0.061 \\
(0.042)\end{array}$ & $\begin{array}{c}0.045 \\
(0.045)\end{array}$ & $\begin{array}{c}0.061 \\
(0.041)\end{array}$ & $\begin{array}{c}0.011 \\
(0.043)\end{array}$ & $\begin{array}{c}0.010 \\
(0.042)\end{array}$ \\
\hline On Reservation & & & $\begin{array}{c}0.047 \\
(0.045)\end{array}$ & $\begin{array}{l}-0.022 \\
(0.039)\end{array}$ & & & & & \\
\hline $\begin{array}{l}\text { ERS quintiles } \\
\text { ERS polynomial }\end{array}$ & Yes & Yes & Yes & Yes & Yes & Yes & Yes & Yes & Yes \\
\hline $\begin{array}{l}\text { Bankruptcy controls } \\
\text { Derogatory Accounts control }\end{array}$ & Yes & Yes & Yes & Yes & Yes & $\begin{array}{l}\text { Yes } \\
\text { Yes }\end{array}$ & Yes & Yes & Yes \\
\hline Age cohort effects & Yes & Yes & Yes & Yes & Yes & Yes & Yes & Yes & Yes \\
\hline Census block group socio-econ controls & Yes & Yes & Yes & Yes & Yes & Yes & Yes & Yes & Yes \\
\hline $\begin{array}{l}\text { Reservation and quarter FE } \\
\text { Inverse Mills Ratio }\end{array}$ & Yes & Yes & Yes & Yes & Yes & Yes & $\begin{array}{c}\text { Yes } \\
0.080^{* *} \\
(0.027)\end{array}$ & Yes & $\begin{array}{c}\text { Yes } \\
0.136^{* * * *} \\
(0.028)\end{array}$ \\
\hline R-squared & 0.2176 & 0.2176 & 0.2135 & 0.2131 & 0.2444 & 0.2189 & & 0.2166 & \\
\hline No. obs. & 34,413 & 34,413 & 31,077 & 31,077 & 34,413 & 34,413 & 34,413 & 33,495 & 33,495 \\
\hline
\end{tabular}

Notes: The outcome variable is logged First Ever Credit Limit. Columns (1)-(6) and (8) present results based on OLS regressions. Columns (7) and (9) present results using Heckman's (1979) two-step approach, where the exclusion restrictions are an indicator for recent hard inquiry and a measure of bank density. In Columns (1) and (2), Census block group socio-economic controls include squared terms for Share Black and Share Hispanic. In Columns (3) and (4), the geographic sample is restricted to areas within 16 km of a reservation, as opposed to areas with $16 \mathrm{~km}$ of any federally recognized tribal land (reservation or off-reservation trust lands). In Columns (8) and (9), sample sizes are reduced due to imperfect matching of postal zip-codes from credit data and zip-code tabulation areas from census data. Reported standard errors are heteroscedasticity-robust and clustered at reservation level. $+, *, * *$, and $* * *$ indicate significance at the $10 \%, 5 \%, 1 \%$, and $0.1 \%$ levels, respectively. Computed using data from the Federal Reserve Bank of New York/Equifax Consumer Credit Panel. 
Table 7: Further Robustness Checks, First Ever Credit Limit

\begin{tabular}{|c|c|c|c|c|c|c|}
\hline Explanatory Variables & $(1)$ & (2) & $(3)$ & (4) & $(5)$ & (6) \\
\hline Share American Indian (block level) & & & $\begin{array}{c}-0.210^{* *} \\
(0.077)\end{array}$ & $\begin{array}{c}-0.215^{* * *} \\
(0.068)\end{array}$ & $\begin{array}{c}-0.151^{*} \\
(0.076)\end{array}$ & $\begin{array}{c}-0.210^{* * *} \\
(0.049)\end{array}$ \\
\hline Share American Indian $2^{\text {nd }}$ Quintile & $\begin{array}{c}0.014 \\
(0.053)\end{array}$ & $\begin{array}{c}0.014 \\
(0.051)\end{array}$ & & & & \\
\hline Share American Indian $3^{\text {rd }}$ Quintile & $\begin{array}{l}-0.059 \\
(0.086)\end{array}$ & $\begin{array}{c}-0.066 \\
(0.087)\end{array}$ & & & & \\
\hline Share American Indian $4^{\text {th }}$ Quintile & $\begin{array}{l}-0.193^{+} \\
(0.115)\end{array}$ & $\begin{array}{l}-0.203^{+} \\
(0.115)\end{array}$ & & & & \\
\hline Share American Indian $5^{\text {th }}$ Quintile & $\begin{array}{c}-0.167^{*} \\
(0.074)\end{array}$ & $\begin{array}{l}-0.169^{*} \\
(0.072)\end{array}$ & & & & \\
\hline On Tribal Land & Yes & Yes & Yes & & Yes & Yes \\
\hline ERS quintiles & Yes & Yes & Yes & Yes & Yes & Yes \\
\hline Bankruptcy controls & Yes & Yes & Yes & Yes & Yes & Yes \\
\hline Derogatory Accounts control & & & & Yes & & \\
\hline Age cohort effects & Yes & Yes & Yes & Yes & Yes & Yes \\
\hline Census block group socio-econ controls & Yes & Yes & Yes & Yes & Yes & Yes \\
\hline Reservation and quarter FE & Yes & Yes & Yes & Yes & Yes & Yes \\
\hline Inverse Mills Ratio & & $\begin{array}{c}0.136^{* * *} \\
(0.027)\end{array}$ & & $\begin{array}{c}0.104 * * * \\
(0.026)\end{array}$ & & \\
\hline R-squared & 0.2174 & & 0.2286 & & 0.1936 & 0.2819 \\
\hline No. obs. & 34,413 & 34,413 & 34,045 & 34,045 & 28,174 & 75,349 \\
\hline
\end{tabular}

Notes: The outcome variable is logged First Ever Credit Limit. Columns (1), (3), (5), and (6) present results based on OLS regressions. Columns (2) and (4) present results using Heckman's (1979) two-step approach, where the exclusion restrictions are an indicator for recent hard inquiry and a measure of bank density. Columns (3) and (4) exclude the top and bottom one percent of new credit limits. In column (5), sample is restricted to individuals for whom Equifax recorded a hard inquiry either in the quarter they acquired the new bankcard or the previous two quarters. In column (6), ERS is measured in the same quarter as the First Credit Limit; to this end, the definition of First Credit Limit is expanded to include credit limits for individuals who either did not appear in previous quarter or whose ERS was missing in previous quarter. Reported standard errors are heteroscedasticity-robust and clustered at reservation level. $+, *, * *$, and *** indicate significance at the $10 \%, 5 \%, 1 \%$, and $0.1 \%$ levels, respectively. Computed using data from the Federal Reserve Bank of New York/Equifax Consumer Credit Panel. 


\section{Table 8: Effect of Share American Indian, First Ever Credit Limit,}

Excluding One State at a Time

\begin{tabular}{lccc}
\hline \hline Excluded State & No. obs. & $(1)$ OLS & $(2)$ Heckit \\
\hline Arizona & 27,444 & $-0.251^{* *}$ & $-0.259^{* * *}$ \\
California & 31,826 & $-0.281^{* * *}$ & $-0.288^{* * *}$ \\
Florida & 32,120 & $-0.264^{* * *}$ & $-0.272^{* * *}$ \\
Minnesota & 33,327 & $-0.277^{* * *}$ & $-0.283^{* * *}$ \\
New Mexico & 31,944 & $-0.273^{* *}$ & $-0.280^{* * *}$ \\
New York & 32,926 & $-0.248^{* *}$ & $-0.255^{* * *}$ \\
Oklahoma & 33,145 & $-0.293^{* * *}$ & $-0.301^{* * *}$ \\
Texas & 32,973 & $-0.263^{* * *}$ & $-0.270^{* * *}$ \\
Washington & 28,177 & $-0.280^{* *}$ & $-0.287^{* * *}$ \\
Wisconsin & 30,633 & $-0.250^{* *}$ & $-0.253^{* * *}$ \\
None (Table 3 Columns (6) and (8)) & 34,413 & $-0.262^{* * *}$ & $-0.269^{* * *}$ \\
\hline \hline
\end{tabular}

Notes: The outcome variable for all regressions is logged First Ever Credit Limit. Column (1) presents estimated coefficients for Share American Indian for OLS specifications as in column (6) of Table 3 while excluding one state at a time. Column (2) presents estimated coefficients for Share American Indian using the Heckit approach as in column (8) of Table 3 while excluding one state at a time. Estimates when no states are excluded (as in Table 3 Columns (6) and (8)) are repeated in the last row. Reported standard errors are heteroscedasticity-robust and clustered at reservation level. *, **, and $* * *$ indicate significance at the $5 \%, 1 \%$, and $0.1 \%$ levels, respectively. Computed using data from the Federal Reserve Bank of New York/Equifax Consumer Credit Panel. 
Figure 1: The distribution of blocks based on Share American Indian
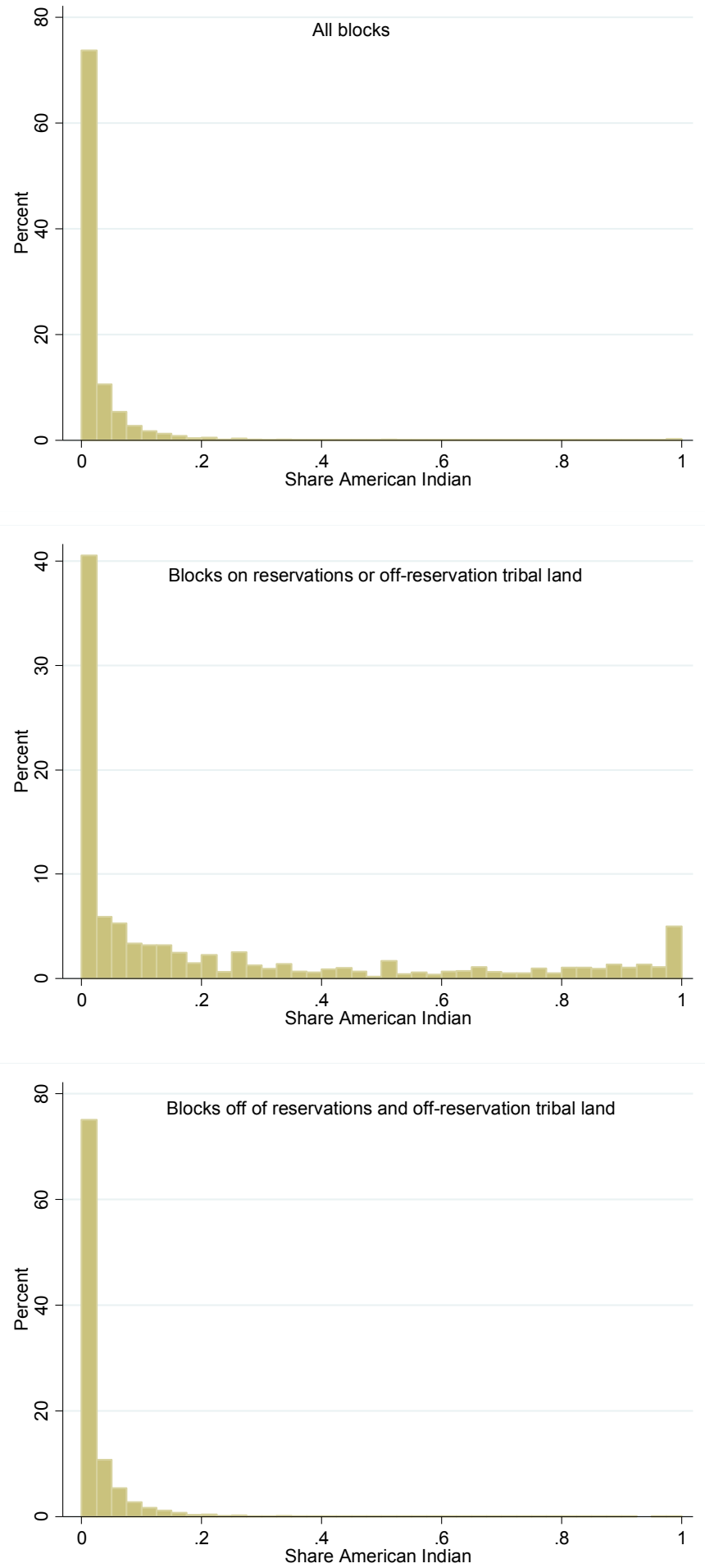

Notes: The figures show the distribution of blocks based on Share American Indian for all blocks (top), blocks on reservations or offreservation trust land (middle), and blocks off of reservations and offreservation trust land (bottom) 
Table A1: Census Block Group Level Socio-Economic Controls

\begin{tabular}{|c|c|c|}
\hline Variable & Description & Source \\
\hline Percent Foreign & Percent of population born in a foreign country. & Census 2000, Summary File 3, Table P21 \\
\hline inc010 & Percent of households with income between $\$ 10,000$ and $\$ 15,000$. & Census 2000, Summary File 3, Table P52 \\
\hline inc $015 \ldots$ inc 150 & Defined analogously to inc010 with number in variable name representing the lower bound of the bracket. & Census 2000, Summary File 3, Table P52 \\
\hline inc200 & Percent of households with income of at least $\$ 200,000$. & Census 2000, Summary File 3, Table 52 \\
\hline Percent Male HS & $\begin{array}{l}\text { Percent of male population (aged } 25+\text { ) with a high school diploma or equivalent and no formal higher } \\
\text { education. }\end{array}$ & Census 2000, Summary File 3, Table P37 \\
\hline Percent Male $>$ HS & Percent of male population (aged 25+) with at least some college education. & Census 2000, Summary File 3, Table P37 \\
\hline Percent Female HS & $\begin{array}{l}\text { Percent of female population (aged } 25+\text { ) with a high school diploma or equivalent and no formal higher } \\
\text { education. }\end{array}$ & Census 2000, Summary File 3, Table P37 \\
\hline Percent Female $>$ HS & Percent of female population (aged $25+$ ) with at least some college education. & Census 2000, Summary File 3, Table P37 \\
\hline Percent Male Married & Percent of male population (aged $15+$ ) who are married. & Census 2000, Summary File 3, Table P18 \\
\hline Percent Male Widowed & Percent of male population (aged $15+$ ) who are widowed. & Census 2000, Summary File 3, Table P18 \\
\hline Percent Male Divorced & Percent of male population (aged $15+$ ) who are divorced. & Census 2000, Summary File 3, Table P18 \\
\hline Percent Female Married & Percent of female population (aged $15+$ ) who are married. & Census 2000, Summary File 3, Table P18 \\
\hline Percent Female Widowed & Percent of female population (aged $15+$ ) who are widowed. & Census 2000, Summary File 3, Table P18 \\
\hline Percent Female Divorced & Percent of female population (aged $15+$ ) who are divorced. & Census 2000, Summary File 3, Table P18 \\
\hline Employment - Population Ratio & Percent of population (aged $16+$ ) that is employed. & Census 2000, Summary File 3, Table P43 \\
\hline Percent Vacant & Percent of housing units that are vacant. & Census 2000, Summary File 3, Table H6 \\
\hline Percent Owner Occupied & Percent of occupied housing units that are owned by the occupant. & Census 2000, Summary File 3, Table H7 \\
\hline Percent Mortgage & Percent of owner-occupied housing units with a mortgage, contract to purchase or similar debt. & Census 2000, Summary File 3, Table H80 \\
\hline Log Housing Unit Median Rent & Log of the median rent among renter-occupied housing units. & Census 2000, Summary File 3, Table H63 \\
\hline Log Housing Unit Median Value & Log of the median value of owner-occupied housing units. & Census 2000, Summary File 3, Table H76 \\
\hline Percent Public Assistance & Percent of households with public assistance income. & Census 2000, Summary File 3, Table P64 \\
\hline Share Black & Share of population (aged 18 or over) that identifies as Black either as single race or in part & Census 2000, Summary File 1, Table P5 \\
\hline Share Hispanic & Share of population (aged 18 or over) that identifies as Hispanic & Census 2000, Summary File 1, Table P6 \\
\hline
\end{tabular}




\section{Table A2: Selection Equation Results for Results in Table 3, Heckman's Two-Step Approach}

\begin{tabular}{|c|c|c|}
\hline Explanatory Variables & For Column (4) in Table 3 & For Column (8) in Table 3 \\
\hline \multicolumn{3}{|l|}{ Census block level } \\
\hline Share American Indian & $\begin{array}{c}-0.076^{* * *} \\
(0.020)\end{array}$ & $\begin{array}{c}-0.057 * \\
(0.029)\end{array}$ \\
\hline On Tribal Land & $\begin{array}{l}-0.002 \\
(0.011)\end{array}$ & $\begin{array}{c}0.009 \\
(0.017)\end{array}$ \\
\hline \multicolumn{3}{|l|}{ Individual level } \\
\hline ERS $2^{\text {nd }}$ Quintile & $\begin{array}{c}0.384 * * * \\
(0.004)\end{array}$ & $\begin{array}{c}0.474 * * * \\
(0.007)\end{array}$ \\
\hline ERS $3^{\text {rd }}$ Quintile & $\begin{array}{c}0.559 * * * \\
(0.005)\end{array}$ & $\begin{array}{c}0.637 * * * \\
(0.007)\end{array}$ \\
\hline ERS $4^{\text {th }}$ Quintile & $\begin{array}{c}0.527 * * * \\
(0.006)\end{array}$ & $\begin{array}{c}0.543 * * * \\
(0.012)\end{array}$ \\
\hline ERS $5^{\text {th }}$ Quintile & $\begin{array}{c}0.517 * * * \\
(0.009)\end{array}$ & $\begin{array}{c}0.333 * * * \\
(0.029)\end{array}$ \\
\hline Bankruptcy Last 10 Years & $\begin{array}{c}0.102 * * * \\
(0.006)\end{array}$ & $\begin{array}{l}0.027^{*} \\
(0.013)\end{array}$ \\
\hline Bankruptcy Last 2 Years & $\begin{array}{c}0.254 * * * \\
(0.009)\end{array}$ & $\begin{array}{c}0.184 * * * \\
(0.022)\end{array}$ \\
\hline Age cohort effects & Yes & Yes \\
\hline Census block group level & & \\
\hline Socio-Economic Controls & Yes & Yes \\
\hline Reservation FE & Yes & Yes \\
\hline Quarter FE & Yes & Yes \\
\hline Exclusion restrictions & & \\
\hline Inquiry & $\begin{array}{c}0.690 * * * \\
(0.004)\end{array}$ & $\begin{array}{c}0.678 * * * \\
(0.006)\end{array}$ \\
\hline Bank Density & $\begin{array}{l}0.031^{*} \\
(0.015)\end{array}$ & $\begin{array}{c}-0.008 \\
(0.024)\end{array}$ \\
\hline No. obs. & $2,461,363$ & $1,205,552$ \\
\hline
\end{tabular}

Notes: The table presents the estimated coefficients and standard errors based on the probit regressions for the selection equation from Heckman's (1979) two-step approach for the results reported in columns (4) and (8) of Table 3. The dependent variable is Gets First Card Next Quarter, a binary outcome equal to 1 the individual transitions from zero to at least one bankcard in the next quarter relative to quarter in which ERS in measured, and 0 otherwise. The sample consists of individual-quarters such that the individual has an ERS but either has no bankcard in that quarter (first column) or never had a bankcard (second column) and the individual is observed in the following quarter. Reported standard errors are heteroscedasticity-robust and clustered at reservation level. * $* *$, and $* * *$ indicate significance at the $5 \%, 1 \%$, and $0.1 \%$ levels, respectively. Computed using data from the Federal Reserve Bank of New York/Equifax Consumer Credit Panel. 